\title{
WPEYW WYSOKOŚCI OPADÓW NA WIELKOŚĆ I SZYBKOŚĆ ODPŁYWU WÓD Z DACHÓW ZIELONYCH
}

\begin{abstract}
Zmiany klimatu, zwłaszcza występowanie gwałtownych i ulewnych deszczy oraz wzrost powierzchni szczelnych na obszarach zurbanizowanych przyczyniają się do zaburzeń w obiegu wody w środowisku. Niekorzystnym zjawiskiem wynikającym z tych zmian jest intensyfikacja spływu wód opadowych, która może powodować okresowe zalewanie ulic, chodników, posesji i budynków oraz może być przyczyną występowania przeciążeń hydraulicznych systemów kanalizacyjnych. W celu ograniczenia tych negatywnych skutków konieczne jest projektowanie zrównoważonych systemów odwadniających, w których stosowane są obiekty i urządzenia zwiększające infiltrację i retencję wód opadowych. Do takich rozwiązań zaliczane są m.in. dachy zielone. W artykule dokonano analizy funkcjonowania zielonych dachów ekstensywnych w aspekcie ich właściwości hydrologicznych. Celem badań było określenie możliwości retencjonowania wód opadowych oraz opóźniania ich odpływu z trzech ekstensywnych dachów zielonych różniących się między sobą układem warstw. Przeprowadzone analizy wykazały, że dachy zielone najlepiej zagospodarowywały wody i opóźniały odpływ w czasie występowania deszczy nie przekraczających w ciągu doby $10 \mathrm{~mm}$. Opady o tej wysokości występowały z największą częstotliwością w latach objętych analizą (2011-2015). Wraz ze wzrostem wysokości opadów możliwości retencjonowania i przetrzymywania wód opadowych, w układzie warstwowym dachów zielonych, były redukowane. $\mathrm{Z}$ tych względów ekstensywne dachy zielone mogą być rozpatrywane jako zrównoważone systemy dla poprawy bilansu wodnego miast, ale w aspekcie ochrony przed skutkami ulewnych opadów o dużej wysokości, ich działanie powinno być wspomagane innymi systemami pozwalającymi odciążyć tradycyjne systemy odwodnieniowe na terenach zurbanizowanych.
\end{abstract}

Słowa kluczowe: dachy zielone, zagospodarowanie wód opadowych, retencja, opóźnienie spływu

\footnotetext{
${ }^{1}$ Ewa Burszta-Adamiak, Uniwersytet Przyrodniczy we Wrocławiu, Wydział Inżynierii Kształtowania Środowiska i Geodezji, Instytut Inżynierii Środowiska, pl. Grunwaldzki 24, 50-363 Wrocław, ewa.burszta-adamiak@up.wroc.pl

2 Autor do korespondencji / corresponding author: Agnieszka Stec, Politechnika Rzeszowska, Wydział Budownictwa, Inżynierii Srodowiska i Architektury, Zakład Infrastruktury i Ekorozwoju, al. Powstańców Warszawy 6, 35-959 Rzeszów, stec_aga@prz.edu.pl
} 


\section{Wprowadzenie}

Postępujące procesy urbanizacji oraz zmiany klimatu niekorzystnie wpływają na warunki hydrologiczne w zlewniach [1]. Według licznych prognoz efektem tych zmian będzie zwiększenie częstotliwości pojawiania się ekstremalnych zjawisk pogodowych, takich jak gwałtowne i nawalne deszcze [2, 3]. Z kolei, rozwój miast i związany z tym wzrost powierzchni nieprzepuszczalnych zaburza obieg wody w środowisku, w wyniku czego następuje obniżenie poziomu wód gruntowych, nadmierne przesuszenie gruntu, zmniejszenie wilgotności powietrza oraz intensyfikacja odpływu wód opadowych [4-6]. Tradycyjne metody ich zagospodarowania, polegające na jak najszybszym odprowadzeniu wód do systemu kanalizacyjnego mogą być przyczyną występowania ciśnieniowych przepływów, zwiększania krotności działania przelewów burzowych oraz pojawienia się powodzi miejskich [7-9]. Taki model zarządzania wodami opadowymi jest niekompatybilny z wymogami nowoczesnej gospodarki wodno-ściekowej opartej na zasadach rozwoju zrównoważonego [10], której głównym celem jest stosowanie rozwiązań technicznych pozwalających na zwiększenie retencji wód opadowych na obszarach zurbanizowanych. Rozwiązania umożliwiające retencję i infiltrację wód opadowych w miejscu gdzie opad wystąpił zaliczane są do zrównoważonych miejskich systemów odwadniających (z ang. Sustainable Urban Drainage Systems - SUDS) [11]. Należą do nich m.in. zbiorniki retencyjne, retencyjno-rozsączające, skrzynki i komory drenażowe, rowy i niecki chłonne oraz zielone dachy [12-16].

Zielone dachy nazywane są również eko-dachami, roślinnymi dachami lub żyjącymi dachami ekologicznymi. Dzięki zastosowaniu do ich budowy wielu warstw o różnych funkcjach posiadają szereg zalet, do których należy zaliczyć: retencję wód opadowych [17-21], opóźnienie spływu wód opadowych [7, 22, 23], zmniejszenie szczytowej fali odpływu [24, 25], racjonalizację zużycia energii w budynku [26, 27], redukcję hałasu [28], ograniczenie efektu „wyspy ciepła" $[29,30]$ oraz obniżenie poziomu zanieczyszczeń w powietrzu [31, 32]. Dodatkowymi korzyściami wynikającymi z zastosowania dachów zielonych jest zwiększenie bioróżnorodności i poprawa mikroklimatu w terenach zurbanizowanych.

Procesy hydrologiczne zachodzące na dachach zielonych są głównym czynnikiem determinującym ich przynależność do zrównoważonych metod zagospodarowania wód opadowych. Z danych literaturowych wynika, iż zdolność retencyjna dla dachu zielonego ekstensywnego mieści się w granicach 40-80\%, natomiast dla intensywnego 80-90\% [6, 23, 33, 34].

Lokalne uwarunkowania klimatyczne, zwłaszcza intensywność i wysokość warstwy opadu, długość trwania okresu bezopadowego, warunki prowadzenia badań oraz rodzaj i konstrukcja dachu zielonego powodują pojawienie się dużych różnic w prezentowanych wynikach badań, co często przysparza problemów w ich interpretacji i uniemożliwia porównanie pomiędzy sobą poszczegól- 
nych wartości parametrów i jednocześnie ocenę skuteczności funkcjonowania dachów zielonych w uwarunkowaniach polskich. Zestawienie wybranych wyników badań w tym zakresie w zależności od lokalizacji dachów zielonych przedstawiono w tabeli 1 . $\mathrm{Z}$ tych względów przenoszenie wyników badań $\mathrm{z}$ jednego regionu do drugiego budzi wiele wątpliwości. Za przykład mogą posłużyć wyniki badań prowadzonych na ekstensywnym dachu zielonym zlokalizowanym na terenie Hamburga, gdzie dach zielony (odnosząc się do rocznej sumy opadów wynoszącej $820 \mathrm{~mm}$ ) może zretencjonować około 60\% wód deszczowych [35], podczas gdy ten sam typ dachu zielonego w Berlinie (opad $500 \mathrm{~mm}$ w ciągu roku) posiada retencyjność wynoszącą 75\% [36].

Tabela 1. Wielkości retencji i opóźnień odpływów z dachów zielonych wykazane przez innych autorów (opracowanie własne)

Table 1. Retention and runoff delay from green roofs demonstrated by other authors (own work)

\begin{tabular}{|c|c|c|c|c|}
\hline $\begin{array}{l}\text { Wysokość opa- } \\
\text { du, mm }\end{array}$ & $\begin{array}{c}\text { Wielkość re- } \\
\text { tencji, \% }\end{array}$ & $\begin{array}{c}\text { Opóźninienie } \\
\text { odpływu, min }\end{array}$ & Lokalizacja & Źródło \\
\hline $1-84$ & $3,6-100$ & $0-709$ & $\begin{array}{l}\text { Leeds, Wielka } \\
\text { Brytania }\end{array}$ & [37] \\
\hline $\begin{array}{c}<2 \\
2-10 \\
>10 \\
\end{array}$ & $\begin{array}{l}72,6-83,9 \\
35,9-46,7 \\
15,7-18,9 \\
\end{array}$ & $48-72$ & $\begin{array}{l}\text { Hong Kong, } \\
\text { Chiny }\end{array}$ & [7] \\
\hline $\begin{array}{c}<20 \\
20-40 \\
>40\end{array}$ & $\begin{array}{l}85 \\
48 \\
32 \\
\end{array}$ & $\begin{array}{c}107,4 \\
238,2 \\
19,8 \\
\end{array}$ & $\begin{array}{l}\text { New York, Sta- } \\
\text { ny Zjednoczone }\end{array}$ & {$[38]$} \\
\hline $\begin{array}{c}<25,4 \\
25,4-76,2 \\
>76,2\end{array}$ & $\begin{array}{l}88 \\
54 \\
48\end{array}$ & 34,9 (średnia) & $\begin{array}{l}\text { Georgia, Stany } \\
\text { Zjednoczone }\end{array}$ & [23] \\
\hline $8-138,2$ & $\begin{array}{c}0-100 \\
\text { (średnia 51,5) }\end{array}$ & $\begin{array}{c}71-1716 \\
\text { (średnia 310) }\end{array}$ & $\begin{array}{c}\text { Genova, Wło- } \\
\text { chy }\end{array}$ & [24] \\
\hline $\begin{array}{c}0-2 \\
2-5 \\
5-10 \\
10-20 \\
20-40 \\
40-80 \\
>80\end{array}$ & $\begin{array}{l}84 \\
68 \\
55 \\
37 \\
25 \\
18 \\
17\end{array}$ & $\begin{array}{c}50 \\
75 \\
120 \\
140 \\
150 \\
100 \\
115\end{array}$ & $\begin{array}{l}\text { Sheffield, } \\
\text { Cornwall, East } \\
\text { Midlands, NW } \\
\text { Scotland, } \\
\text { Wielka } \\
\text { Brytania }\end{array}$ & [39] \\
\hline $0,2-34,3$ & $46,9-98,8$ & $110-2290$ & $\begin{array}{l}\text { Adelaide, Aus- } \\
\text { tralia }\end{array}$ & {$[40]$} \\
\hline
\end{tabular}

Z wyżej wymienionych czynników największy wpływ na wielkość retencji wód opadowych na dachu zielonym, jak wynika $\mathrm{z}$ wielu badań, prowadzonych głównie zagranicą, ma wysokość warstwy opadu. Stąd autorki podjęły się w niniejszym artykule analizy wpływu tego czynnika na funkcjonowanie dachów zielnych w warunkach wrocławskich. 
Celem artykułu jest dokonanie oceny możliwości ekstensywnych dachów zielonych w zatrzymywaniu i opóźnianiu spływów w czasie zdarzeń opadowych o różnej wysokości, które wystąpiły w warunkach wrocławskich w latach 2011-2015. Do analizy wykorzystano dane otrzymane na stanowiskach badawczych zlokalizowanych na Uniwersytecie Przyrodniczym we Wrocławiu.

\section{Metodyka badań}

\subsection{Charakterystyka obiektu badawczego}

Badania prowadzono na ekstensywnych dachach zielonych, wykonanych w ska-li półtechnicznej ( $\mathrm{w}$ formie kuwet o wymiarach zewnętrznych $2,4 \mathrm{~m} \times$ $1,2 \mathrm{~m} \times 0,35 \mathrm{~m}$ (długość/szerokość/wysokość), wypełnionych układem warstw o różnej konfiguracji (rys. 1). W konstrukcji dachów zastosowano substraty, które są powszechnie stosowane na dachach zielonych. Są to produkty wykonane zgodnie z wytycznymi FLL [41].

Miąższość substratów na dachach była jednakowa i wynosiła $10 \mathrm{~cm}$. Stanowiska badawcze znajdowały się na dachu Centrum Naukowo-Dydaktycznego, budynku przynależnego do Uniwersytetu Przyrodniczego we Wrocławiu. Aparatura pomiarowa dla opadów i odpływów była zlokalizowana na dachu tego samego budynku, na którym znajdowały się stanowiska badawcze. Pomiary wysokości opadów były prowadzone w sposób ciągły za pomocą distrometru laserowego firmy OTT MESSTECHNIK GmbH\&Co.KG. Do pomiaru odpływów z dachów ekstensywnych posłużyły mierniki Naja 0404. Wyniki tych pomiarów były zapisywane w pamięci rejestratora Memory Hilogger 8430-20 firmy HIOKI $\mathrm{z}$ interwałem czasowym $30 \mathrm{~s}$.

Retencję w niniejszym artykule określano jako procent wysokości opadu, która nie odpłynęła ze stanowisk w stosunku do wysokości opadu przypadającej na powierzchnię dachu. Opóźnienie spływów interpretowano jako różnicę w czasie pomiędzy początkiem opadu a zarejestrowanym początkiem odpływu. 

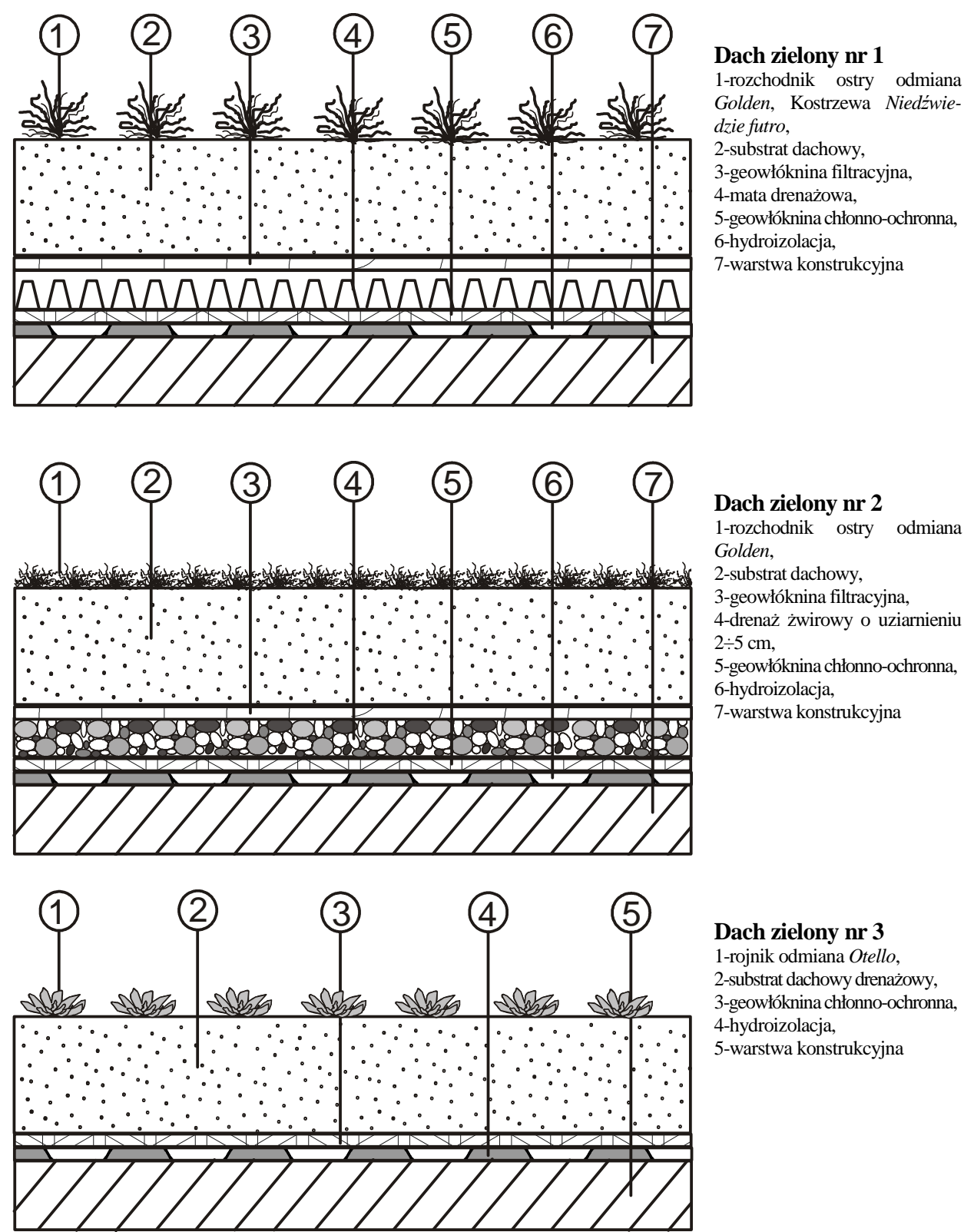

Rys. 1. Układ warstw w badanych dachach zielonych (opracowanie własne)

Fig. 1. Structure of layers in the analyzed green roofs (own study) 


\subsection{Charakterystyka opadów objętych analizą}

Obliczone, na podstawie danych z pomiarów, wartości retencji i opóźnienia spływów, interpretowano w odniesieniu do opadów o różnej wysokości, które wystąpiły w latach 2011-2015. Struktura opadów o danej wysokości w poszczególnych latach została przedstawiona na rys. 2. Jako zdarzenie opadowe potraktowano, podobnie jak inni autorzy [37], opady, pomiędzy którymi okres bezopadowy wynosił co najmniej $6 \mathrm{~h}$. Pomimo objęcia w badaniach wszystkich pór roku, nie uwzględniano opadów śniegu, które wystąpiły w okresie zimowym. Najmniejsza wysokość opadów deszczu, którą poddawano analizie wynosiła $0,5 \mathrm{~mm}$. Z okresu pomiarowego usunięto także pojedyncze opady, które ze względu na chwilowe awarie urządzeń pomiarowych nie zostały prawidłowo zarejestrowane. W sumie wielkości retencji wodnej oraz opóźnienia spływów przeanalizowano dla 200 zdarzeń opadowych o wysokości warstwy opadów mieszczącej się w granicach 0,5 mm -76,3 mm.

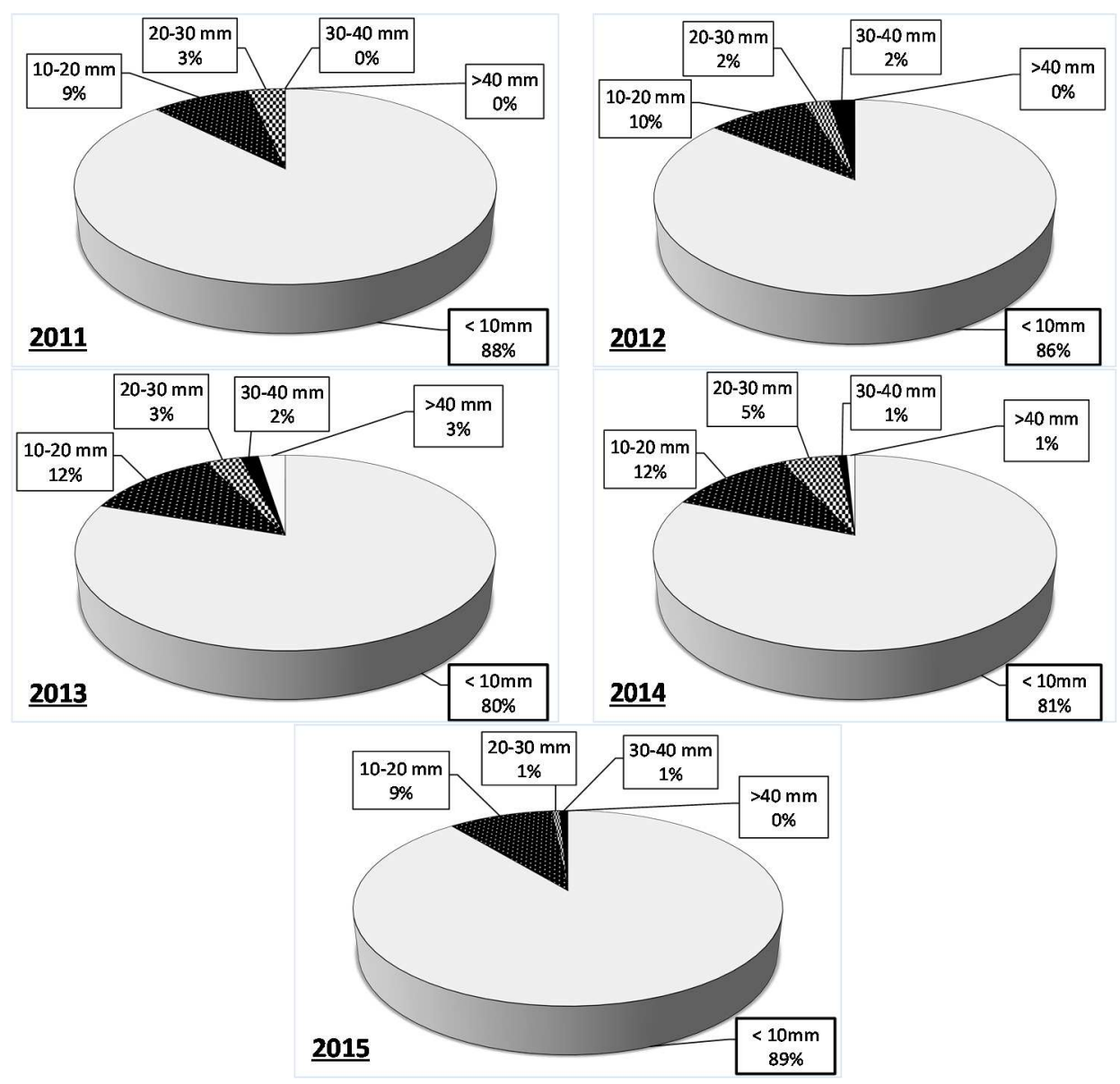

Rys. 2. Struktura wysokości opadów z lat 2011-2015

Fig. 2 The structure of rainfall depth from 2011 to 2015 


\section{Analiza wyników i dyskusja}

Ze struktury opadów, które wystąpiły w okresie pomiarowym (rys. 2) wyni$\mathrm{ka}$, że zdecydowana większość (> 80\%) to opady poniżej $10 \mathrm{~mm}$. Opady o dobowej warstwie przekraczającej $20 \mathrm{~mm}$ stanowiły $2-4 \%$ obserwacji. Jedynie w latach 2013 i 2014 zarejestrowano opady o dobowej wysokości przekraczającej $40 \mathrm{~mm}$. Choć stanowiły one niecałe $3 \%$ w skali roku, skutki ich wystąpienia były odczuwalne w polskich miastach. W roku 2013 w okresie maj-lipiec występowały gwałtowane ulewy powodujące lokalne podtopienia niemal w całym kraju. Podobnie było w roku 2014, w którym w maju gwałtowne burze i ulewne deszcze, szczególnie w południowej i we wschodniej Polsce, powodowały wezbrania w rzekach i były przyczyną występowania podtopień.

Wielkość retencji wodnej oraz opóźnienia spływów na poszczególnych stanowiskach z podziałem na kategorie wysokości opadów zostały przedstawione odpowiednio na rysunku 3-6. Średnia retencja na dachach zielonych kształtowała się na poziomie $77,7 \%$ dla dachu nr 1,75,3\% dla dachu nr 2 oraz 78,3\% dla dachu $\mathrm{nr} 3$ (rys. 3). Mediany retencji kształtowały się na poziomie $95 \%$ dla opadów o wysokości do $10 \mathrm{~mm}$. W kategorii wysokości opadów od 10 do $20 \mathrm{~mm}$ możliwości zatrzymywania wody opadowej zmniejszyły się (mediana od 66,8 \% do 87,8 \%). Dla większości zdarzeń o wysokości opadu do $10 \mathrm{~mm}$ nie odnotowywano spływów z dachów zielonych. Najwyższe retencje deszczy zaobserwowano dla opadów o wysokości do około $30 \mathrm{~mm}$ (rys. 4).Widoczna redukcja w zdolnościach zatrzymywania wód na dachach zielonych nastąpiła przy opadach powyżej $30 \mathrm{~mm}$. Opady o wysokości powyżej $40 \mathrm{~mm}$ tylko w niewielkim stopniu zostały zatrzymane na dachu (rys.5). Znaczna objętość wód, pochodząca z tej kategorii opadów, została przekształcona w spływy. Wynika to z ograniczeń pojemności wodnej warstw konstrukcyjnych dachu zielonego, w tym głownie substratu i warstwy drenażowej, gdzie zatrzymywane są największe ilości wody w trakcie opadów.

Możliwości zatrzymywania wód opadowych na dachach zielonych mają swoje odzwierciedlenie w wielkościach opóźnień spływów. Największe opóźnienia zaobserwowano na dachu zielonym nr 1 (średnia 3,3 h). Dla porównania uśredniona wartość opóźnienia z dachów nr 2 i 3 wynosiła 1,5 h. Warto jednak zauważyć, że pomimo różnic w minimalnych i maksymalnych wielkościach opóźnien, rejestrowanych dla opadów o różnej wysokości, wartości ich median są na zbliżonym do siebie poziomie (rys.6). Dla dachu zielonego mieszczą się one w graniach od 5,4 min do 1,75 h, dla dachu nr 2 od 1,8 min do 21 min oraz dla dachu nr 3 od 1,2 min do 48 min. Największe opóźnienia odpływów na wszystkich stanowiskach badawczych wystąpiły w czasie deszczy o wysokości nie przekraczającej $20 \mathrm{~mm}$. Według danych zawartych w (SPA, 2013) deszcze o wysokości > 20 mm klasyfikowane są jako opady ulewne, które obok powodzi, stanowią istotne zagrożenie dla infrastruktury miejskiej. Podobne informacje można znaleźć w [42], z tym, że opady w tym dokumencie podzielone zostały na trzy kategorie w zależności od stopnia zagrożenia. Opad o wysokości większej bądź równej $30 \mathrm{~mm}$ może powodować m.in. lokalne podtopienia, 
zalanie pomieszczeń w piwnicach i suterenach oraz utrudnienia w ruchu komunikacyjnym. Przy deszczach powyżej $20 \mathrm{~mm}$ dobowej wysokości, spływ z analizowanych dachów zielonych pojawiał się stosunkowo szybko po rozpoczęciu opadu.
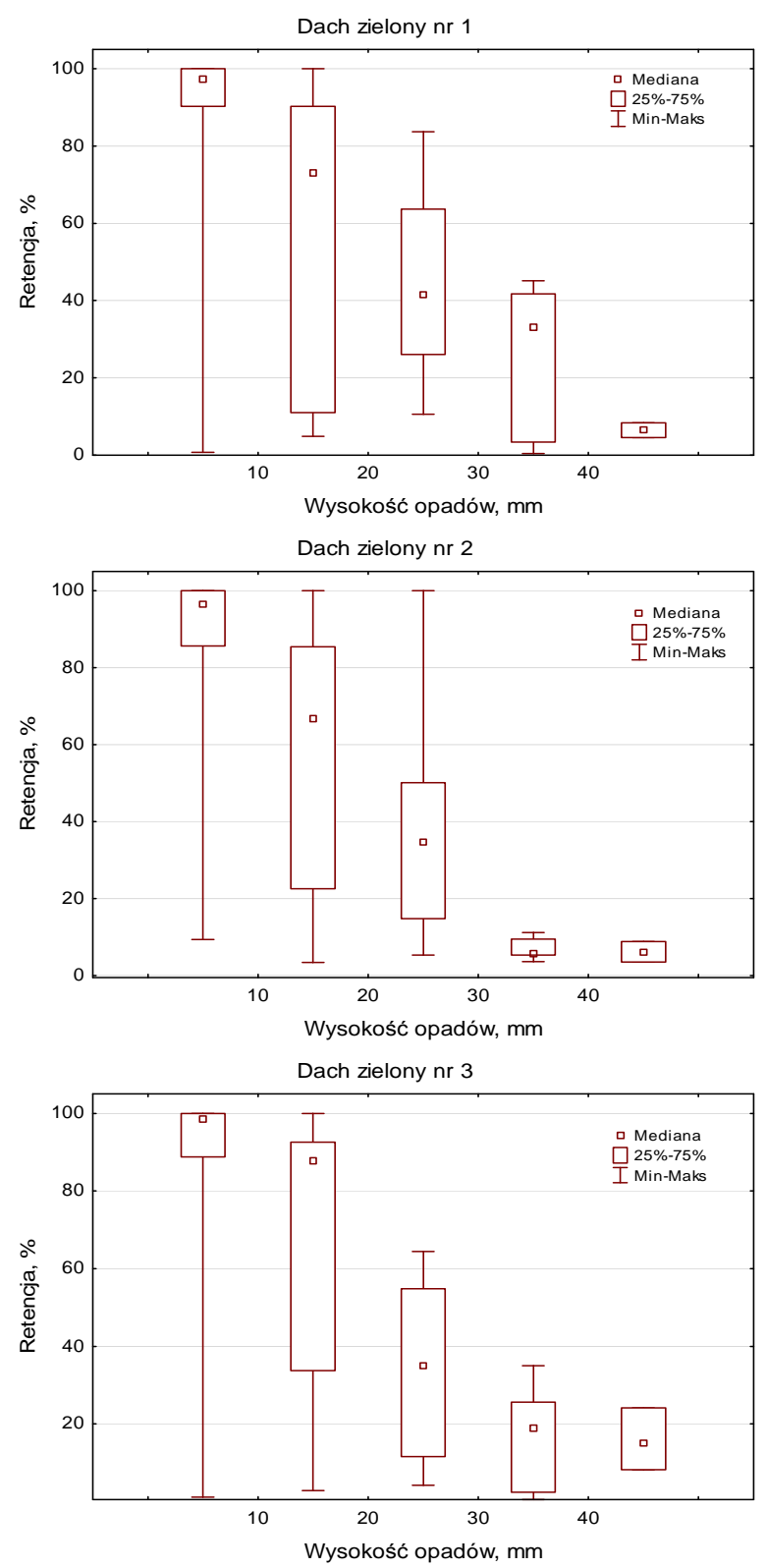

Rys. 3. Wielkości retencji w zależności od wysokości opadu na poszczególnych dachach zielonych (opracowanie własne)

Fig. 3. Retention in relation to rainfall depth on the green roofs (own study) 


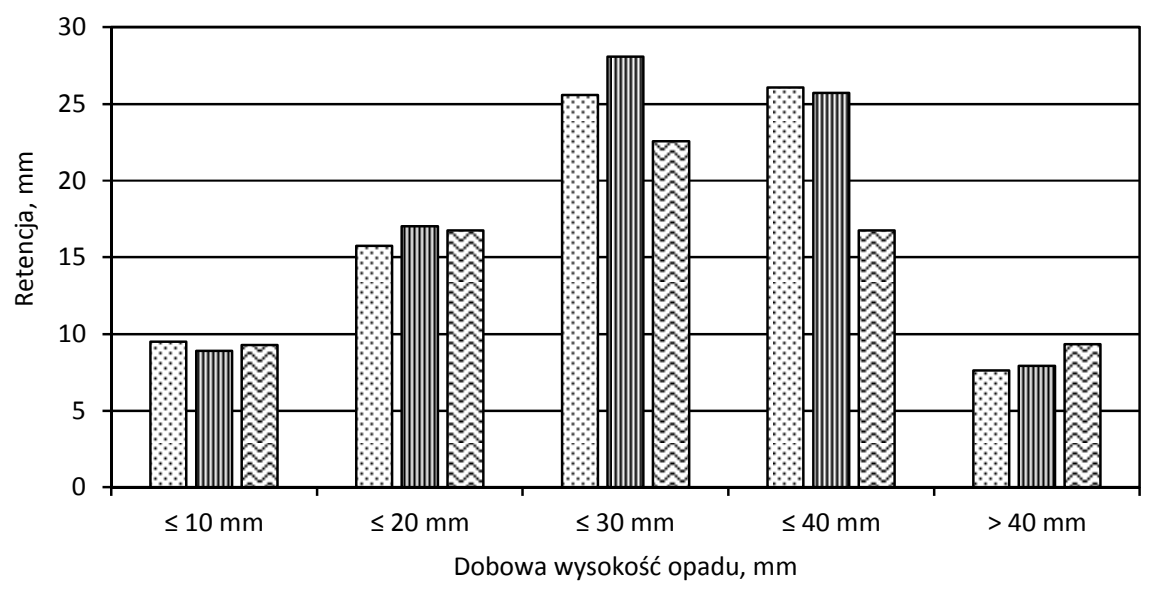

Dach zielony nr 1 四 Dach zielony nr 2 Q Dach zielony nr 3

Rys. 4. Maksymalne wielkości retencji bezwzględnej ( w mm) w zależności od wysokości opadu na poszczególnych dachach zielonych (opracowanie własne)

Fig. 4. Maximum retention (in $\mathrm{mm}$ ) in relation to rainfall depth on the green roofs (own study)

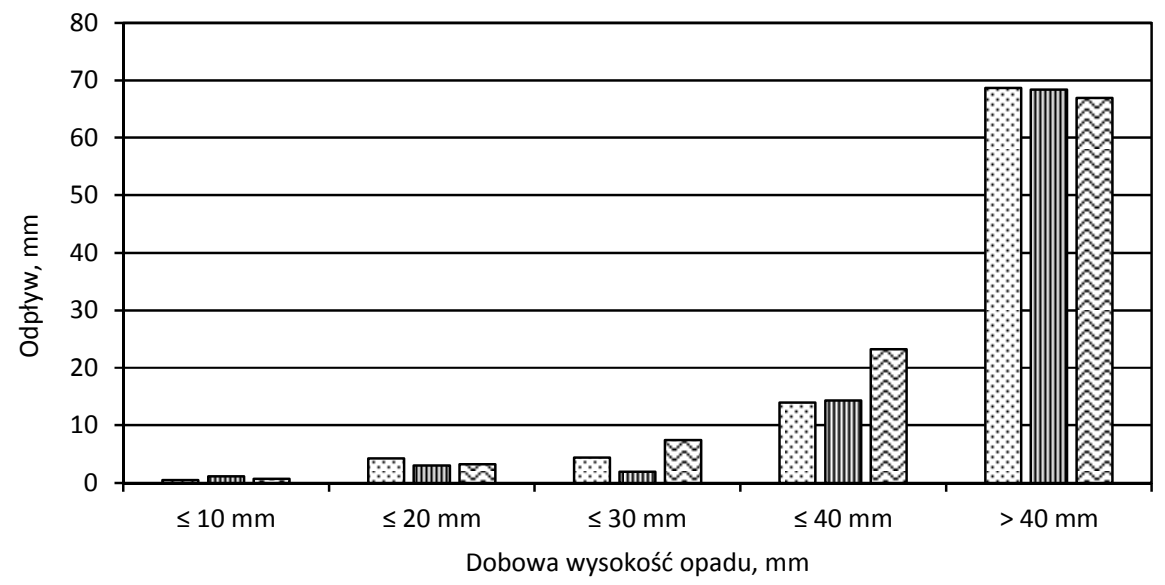

DDach zielony $\mathrm{nr} 1$ 四 Dach zielony $\mathrm{nr} 2$ Dach zielony $\mathrm{nr} 3$

Rys. 5. Wielkości odpływu wód z uwzględnieniem maksymalnej bezwzględnej retencji w danej kategorii opadów na poszczególnych dachach zielonych (opracowanie własne)

Fig. 5. Rainwater runoff with taking into account the maximum retention in an each rainfall category on the green roofs (own study) 

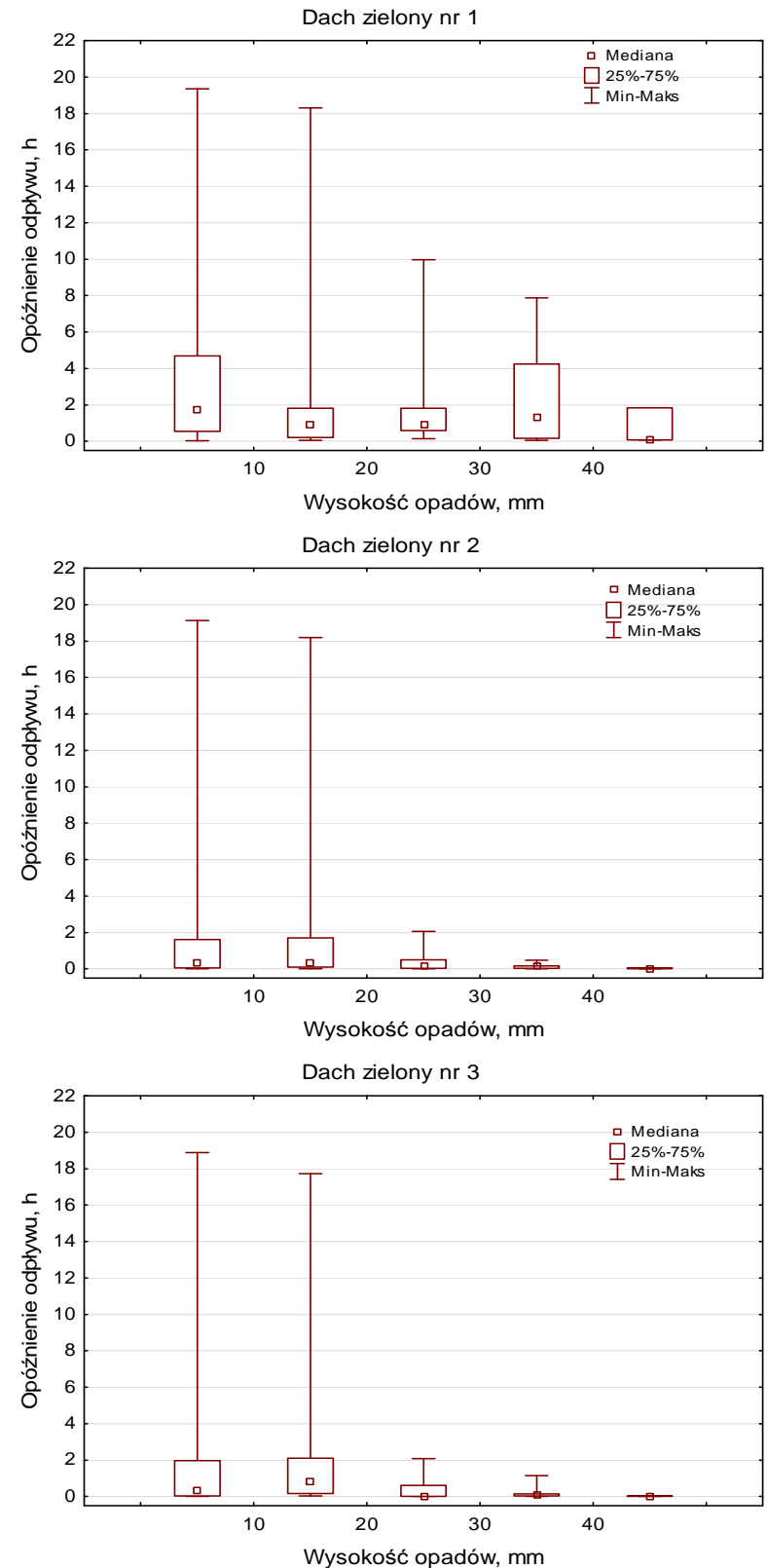

Rys. 6. Wielkości opóźnienia spływów w zależności od wysokości opadu na poszczególnych dachach zielonych (opracowanie własne)

Fig. 6. Runoff delay in relation to rainfall depth on the green roofs (own study) 
Przeprowadzone analizy wykazały, że dla tej kategorii opadów na ekstensywnych dachach zielonych średnia retencja wynosiła $35,3 \%$ dla dachu $\mathrm{nr} 1$, $21,9 \%$ dla dachu $\mathrm{nr} 2$ oraz 27,5\% dla dachu nr 3. Średnie opóźnienie odpływu zarejestrowane dla tej kategorii opadów było na poziomie 20 min dla dachu $\mathrm{nr} 2$ i 3 oraz 1,5 h dla dachu nr 1 . Ze wszystkich badanych dachów zielonych, dach nr 1 opóźniał odpływ z największą skutecznością. Prawdopodobnie wynikało to z konstrukcji dachu zielonego. Pomimo układu wielowarstwowego we wszystkich analizowanych dachach, tylko dach $\mathrm{nr} 1$ miał zastosowaną warstwę drenażową w formie mat kubełkowych, stosowanych w celu zwiększenia możliwości przetrzymywania wody na dachach dla poprawy zarówno właściwości hydrologicznych dachów jak i warunków bytowania roślin.

\section{Podsumowanie i wnioski}

Aktualne tendencje rozwoju systemów odwodnieniowych miast ukierunkowane są na wspomaganie tradycyjnych systemów kanalizacyjnych rozwiązaniami zapewniającymi zagospodarowanie wód w miejscu opadu. Idealnie w ten trend wpisują się dachy zielone. Korzyści ze stosowania dachów zielonych jest bardzo wiele, poczynając od aspektów przestrzennych przez przyrodnicze i ekonomiczne, a na społecznych kończąc. Bardzo ważną zaletą dachów zielonych, z punktu widzenia zrównoważonej gospodarki wodami opadowymi na terenach zurbanizowanych, jest możliwość znacznej redukcji ilości wód odprowadzanych do systemu kanalizacyjnego. W dobie zmian klimatu i coraz częstszego występowania ekstremalnych zjawisk pogodowych nabiera to jeszcze większego znaczenia. Możliwości okresowego zatrzymania wody w warstwach dachu uzależnione są między innymi od charakterystyki deszczu, zwłaszcza jego wysokości. Przeprowadzone analizy opierające się na ocenie funkcjonowania zielonych dachów ekstensywnych w czasie występowania rzeczywistych epizodów opadowych pozwalają na sformułowanie następujących wniosków:

1. Ekstensywne dachy zielone, dzięki wielowarstwowej konstrukcji, zagospodarowały prawie wszystkie wody pochodzące $\mathrm{z}$ opadów o dobowej wysokości do $10 \mathrm{~mm}$. Oznacza to, że dachy zielone dzięki zachodzącym na nich procesom hydrologicznym (głównie retencja, detencja, ewapotranspiracja i infiltracja) były w stanie przyjąć większość opadów, które wystąpiły w okresie pięciu lat $\mathrm{w}$ warunkach meteorologicznych Wrocławia. Pomimo, że są to wysokości opadów które zazwyczaj nie powodują zagrożeń podtopieniami, a ich spływy są przyjmowane przez system odwodnieniowy miasta, korzyści hydrologiczne dachów zielonych nie powinny być marginalizowane. Opady poniżej $10 \mathrm{~mm}$, stanowiły w skali roku ponad $80 \%$ zdarzeń opadowych, a sumarycznie tworzyły ponad $300 \mathrm{~mm}$ warstwę opadów. Pozwala to na wyliczenie, że każdy $\mathrm{m}^{2}$ dachu zielonego przyjął prawie $300 \mathrm{dm}^{3}$ wody w każdym roku, ograniczając w ten sposób ilości wód opadowych spływających bezpośrednio do odbiorników. Wykonywanie dachów zielonych o większych powierzch- 
niach oznaczałoby tym samym większą objętość wody, którą można zatrzymać na miejscu opadu.

2. Przy opadach o wysokości dobowej powyżej $30 \mathrm{~mm}$ badania wykazywały redukcję skuteczności $\mathrm{w}$ zatrzymaniu wód deszczowych na dachach zielonych. Mediana retencji wodnej dla tej kategorii opadów, kształtowała się, w zależności od dachu, w granicach 5,5\%( dach $\mathrm{nr}$ 2) do 33,2\% (dach $\mathrm{nr} 1$ ). Było to wielokrotnie mniej niż w przypadku zarejestrowanej mediany retencji wodnej dla deszczy o dobowej wysokości opadów do $20 \mathrm{~mm}$.

3. Wysokość opadów miała także wpływ na opóźnianie spływów wód opadowych. Największe opóźnienia odpływów na wszystkich stanowiskach badawczych były rejestrowane w czasie występowania deszczy o wysokości dobowej mniejszej niż $20 \mathrm{~mm}$. Przy deszczach powyżej tej wielkości, spływ z dachów zielonych pojawiał się po kilku lub kilkunastu minutach po rozpoczęciu opadu.

4. Najlepsze zdolności opóźnienia spływów opadowych wykazywał dach zielony $\mathrm{nr} 1, \mathrm{z}$ zastosowaniem warstwy drenażowej w formie mat kubełkowych. Dla tego dachu, średnie opóźnienie odpływu wynosiło 3,3 h i było ponad dwukrotnie większe niż to zarejestrowane dla pozostałych analizowanych dachów.

5. Wykazane wielkości retencji wodnej i opóźnienia spływów pozwalają na stwierdzenie, że budowa dachów zielonych na szerszą skalę w miastach może wykazywać pozytywny wpływ na bilans wodny terenów zurbanizowanych oraz poprawę warunków wilgotnościowych na danym terenie (poprawę mikroklimatu). Ze względu jednak na ograniczone możliwości zatrzymywania i przetrzymywania spływów opadowych w czasie większych opadów, aby minimalizować ryzyko wystąpienia niekorzystnych skutków deszczy nawalnych, konieczne jest wspomaganie dachów zielonych innymi rozwiązaniami ukierunkowanymi na zrównoważoną gospodarkę wodną w miastach.

6. Korzyści dachów zielonych dla miejskiej gospodarki wodnej wiążą się także z redukcją objętości spływających wód opadowych trafiających bezpośrednio do kanalizacji. Przy posiadaniu charakterystyk opadów i spływów z dachów zielonych z tak długiego okresu monitoringu, celowym wydaje się kontynuowanie badań w kierunku wykorzystania dostępnych modeli numerycznych i przeprowadzenia analiz symulacyjnych w celu określenia w skali większego obszaru (zlewni, miasta, dzielnicy) wpływu dachów zielonych na redukcję odpływu dostającego się do istniejących systemów odprowadzających wody opadowe do odbiorników. Temat ten będzie przedmiotem analiz przyszłej publikacji. 


\section{Literatura}

[1] Jiang Y., Fu P., Weng O.: Assessing the Impacts of Urbanization-Associated Land Use/Cover Change on Land Surface Temperature and Surface Moisture: A Case Study in the Midwestern United States, Remote Sens., 2015, 7, 4880-4898.

[2] Kaźmierczak B, Kotowski A.: The influence of precipitation intensity growth on the urban drainage systems designing, Theor Appl Climatol, 2014, 118, 285-296.

[3] SPA, Strategiczny plan adaptacji dla sektorów i obszarów wrażliwych na zmiany klimatu do roku 2020 z perspektywą do roku 2030. Ministerstwo Środowiska, Warszawa, 2013.

[4] Vesuviano G., Stovin V.: A generic hydrological model for a green roof drainage layer, Water Sci. Technol., 2013, 68, 769-775.

[5] Palla A., Gnecco I., Lanza L.G.: Compared performance of a conceptual and a mechanistic hydrologic models of a green roof. Hydrol. Process., 2012, 26, 73-84.

[6] Getter K.L., Rowe B.D., Andresen J.A.: Quantifying the effect of slope on extensive Green roof stormwater retention, Ecol. Eng., 2007, 31, 225-231.

[7] Gwendolyn K.L. Wong, C.Y. Jim: Quantitative hydrologic performance of extensive green roof under humid-tropical rainfall regime, Ecological Engineering, 2014, 70, 366-378.

[8] Zawilski M.: Charakterystyka ekstremalnych zjawisk opadowych w aspekcie badania przyczyn zalewania terenów miast. Materiały VII Ogólnopolskiej Konferencji Szkoleniowej pt. Wody opadowe - aspekty prawne, ekonomiczne i techniczne. 23-24 kwietnia 2012 Łódź, 34-42.

[9] Thorndahl S., Willems P.: Probabilistic modelling of overflow, surcharge and flooding in urban drainage using the first-order reliability method and parameterization of local rain series, Water Res., 2008, 42 (1-2), 455-466.

[10] Dyrektywa 2000/60/WE Parlamentu Europejskiego i Rady z dnia 23 października 2000 roku ustanawiająca ramy wspólnotowego działania w dziedzinie polityki wodnej.

[11] Lamera C., Becciu G, Rulli M.C., Rosso R.: Green roofs effects on the urban water cycle components, Procedia Engineering, 2014, 70, 988-997.

[12] Stec A.: Model optymalizacyjny retencyjnego zbiornika rurowego. Czasopismo Inżynierii Lądowej, Środowiska i Architektury - Journal of Civil Engineering, Environment and Architecture, JCEEA, t. XXXIII, z. 63 (2/II/2016), 445-455.

[13] Suligowski Z.: Alternatywa dla wód opadowych, Wodociągi i Kanalizacja, nr 4/2008.

[14] Słyś D.: Zrównoważone systemy odwodnienia miast. Dolnośląskie Wydawnictwo Edukacyjne, Wrocław 2013.

[15] Dziopak J.: Modelowanie wielokomorowych zbiorników retencyjnych w kanalizacji. Oficyna Wydawnicza Politechniki Rzeszowskiej, Rzeszów 2004.

[16] Burszta-Adamiak E.: Zielone dachy jako element zrównoważonych systemów odwadniających na terenach zurbanizowanych. Wydawnictwo Uniwersytetu Przyrodniczego we Wrocławiu, Wrocław, 2014.

[17] Burszta-Adamiak E., Mrowiec M.: Modelling of green roofs' hydrologic performance using EPA's SWMM, Water Science and Technology, 2013, 68, 36-42.

[18] Speak A.F., Rothwell J.J., Lindley S.J., Smith, C.L.: Rainwater runoff retention on an aged intensive green roof, Sci. Total Environ., 2013, 461-462, 28-38. 
[19] Schroll E., Lambrinos J., Righetti T., Sandrock D.: The role of vegetation in regulating stormwater runoff from green roofs in a winter rainfall regime, Ecol. Eng., 2011, 37, 595-600.

[20] DeNardo J.C., Jarrett A.R., Manbeck H.B., Beattie D.J., Berghage R.D.: Stormwater mitigation and surface temperature reduction by green roofs, Trans. ASAE, 2005, 48 (4) pp. 1491-1496.

[21] Sims A.W., Robinson C.E., Smart C.C., Voogt J.A., Hay G.J., Lundholm J.T., Powers B., O'Carroll D.M.: Retention performance of green roofs in three different climate regions, Journal of Hydrology, 2016, In Press.

[22] Spolek G.: Performance monitoring of three ecoroofs in Portland, Oregon. Urban Ecosyst. 2008, 11, 349-359.

[23] Carter T.L., Rasmussen T.C.: Hydrologic behaviour of vegetated roofs, Journal of the American Water Resources Association, 2006, 42, 1261-1274.

[24] Palla A., Gnecco I., Lanza L.G.: Hydrologic Restoration in the Urban Environment Using Green, Water 2010, 2, 140-154.

[25] Voyde E., Fassman E., Simcock R.: Hydrology of an extensive living roof under sub-tropical climate conditions in Auckland, New Zealand. J. Hydrol., 2010, 394, 384-395.

[26] Wong N.H., Chen Y., Ong C.L., Sia A.: Investigation of thermal benefits of rooftop garden in the tropical environment, Build Environ, 2003, 38, 261-70.

[27] Ouldboukhitine S., Belarbi R., Jaffal I., Trabelsi A.: Assessment of green roof thermal behavior: a coupled heat and mass transfer model, Build Environ 2011, 46, 2624-31.

[28] Van Renterghem T., Booteldooren D.: Reducing the acoustical façade load from traffic with green roofs, Build. Environ., 2009, 44, 1081-1087.

[29] Alexandri E., Jones P.: Temperature decreases In an Urban canyon due to Green walls and gren roofs In diverse climates, Building and Environment, 2008, 43, 480-493.

[30] Bowler D.E., Buyung-Ali L., Knight T.M., Pullin A.S.: Urban greening to cool towns and cities: a systematic review of the empirical evidence, Landscape and Urban Planning, 2010, 97, 147-155.

[31] Yang J., Yu Q., Gong P.: Quantifying air pollution removal by green roofs in Chicago, Atmos. Environ., 2008, 42, 7266-7273.

[32] Jian-feng Li, Onyx W.H. Wai, Y.S. Li, Jie-min Zhan, Y. Alexander Ho, James Li, Eddie Lam. Effect of green roof on ambient CO2 concentration, Building and Environment, Volume 45, 2010, 2644-2651.

[33] Fassman-Beck E., Voyde E., Simcock R., Hong Y.S.: 4 Living roofs in 3locations: does configuration affect runoff mitigation? J. Hydrol., 2013, 490, 11-20.

[34] Gregoire B.G., Clausen J.C.: Effect of a modular extensive green roof on stormwater runoff and water quality, Ecol. Eng. 2011, 37, 963-969.

[35] Liesecke H. J.: Extensive begrünung bei 5 dachneigung, Stadt und Grün, 1999, 48(5), 337-346.

[36] Köhler M., Schmidt M.: Langzeituntersuchungen an begrünten Dächern in Berlin. Dach+Grün, 1999, 8, 12-18. 
[37] Nawaz R., McDonald A., Postoyko S.: Hydrological performance of a full-scale extensive green roof located in a temperate climate, Ecological Engineering, 2015, $82,66-80$.

[38] Hakimdavar R., Culligan P.J., Finazzi M., Barontini S., Ranzi R.: Scale dynamics of extensive green roofs: Quantifying the effect of drainage area and rainfall characteristics on observed and modeled green roof hydrologic performance, Ecological Engineering, 2014, 73, 494-508.

[39] Stovin V., Vesuviano G., De-Ville S.: Defining green roof detention performance, Urban Water Journal, 2015, 1-15. http://dx.doi.org/10.1080/1573062X.2015.1049279

[40] Razzaghmanesh M., Beecham S.: The hydrological behaviour of extensive and intensive green roofs in a dry climate, Science of The Total Environment, 2014, 499, 284-296.

[41] FLL: Wytyczne niemieckiego Towarzystwa Naukowo-Badawczego Krajobrazu i Rolnictwa tzw. wytyczna FLL (niem. Forschungsgesellschaft Landschaftsentwicklung Landschaftsbau e.V), 2008.

[42] Niebezpieczne zjawiska meteorologiczne. Geneza, skutki, częstość występowania. Instytut Meteorologii i Gospodarki Wodnej Państwowy Instytut Badawczy. Warszawa, 2013.

\title{
IMPACT OF THE RAINFALL HEIGHT ON RETENTION AND RUNOFF DELAY FROM GREEN ROOFS
}

\begin{abstract}
S u m m a r y
Climate change, especially the occurrence of violent and heavy rainfall and an increase in the sealed surface in urban areas contribute to disturbances in the circulation of water in the environment. Disadvantageous phenomenon resulting from these changes is to increase the rainwater runoff, which can cause temporary flooding of streets, sidewalks, residential areas and buildings. The increase in the volume of sewage discharged to sewers contribute to the emergence of adverse phenomena of hydraulic overload in these systems. In order to reduce these negative impacts it is necessary to design sustainable drainage systems, in which are used the facilities and equipment to increase rainwater retention and infiltration. Such solutions include, among others, green roofs. In the article, the analysis of the functioning of extensive green roofs in the aspect of their hydrological properties was carried out. The aim of the study was to determine the possibility of rainwater retention and runoff delay from three extensive green roofs with different system layers. The conducted analysis have shown that the green roofs efficiently retained water and delayed runoff during rainfall with a depth not more than $10 \mathrm{~mm}$. Precipitation of this depth occurred with the greatest frequency in the years covered by the analysis (2011-2015). With an increase the depth of rainfall the possibilities of rainwater retention capacity of green roofs have been reduced. For these reasons the extensive green roofs can be considered as sustainable systems for the improvement of water balance of the cities, but in the aspect of protection against the effects of heavy precipitation in large depth, their operation should be supported by other systems that allow offload the traditional drainage systems in urban areas.
\end{abstract}

Keywords: green roofs, storm water management, retention, runoff delay

Przestano do redakcji: $10.12 .2016 r$.

Przyjęto do druku: 31.03.2017 r. 